\title{
The Reforming of Money Politics Cases In Election Law As Corruption Crime
}

\author{
Wawan Setiyawan*) and Anis Mashdurohatun**) \\ *)Indonesian General Attorney, E-mail: wawansetiyawan1208@gmail.com \\ ${ }^{* *}$ ) Faculty of Law Universitas Islam Sultan Agung
}

\begin{abstract}
This research aims to knowing and analyzing the reformulation of money politics in the election law as a criminal act of corruption. The research method in writing this journal uses normative (doctrinal) research methods. Based on the research, it is concluded that reformulation of money politics in the election law as a corruption crime can be done by including a clause on political corruption as a special offense in the General Election Law so that it can be a strong legal basis for law enforcement officials to take steps - preventive or repressive measures to realize clean elections and corruption-free politics.
\end{abstract}

Keywords: Criminal Act; Money Politics; Corruption.

\section{Introduction}

Politics comes from the Arabic language called Siyasah, which is then translated into tactics. In English it is called politic, which means clever and wise, in everyday speech the word is defined as a means used to achieve goals. ${ }^{1}$ While the Big Indonesian Dictionary ${ }^{2}$ defines politics as (knowledge) about the state administration or state (such as about the system of government, the basis of government). As for the Indonesian Encyclopedia ${ }^{3}$ explained that politics is a concept that deals with matters of government. The origin of the word politics comes from the word polis, which means city-state, the word politics means there is a special relationship between humans who live together in the city, in that relationship arises the rules of authority, official behavior, legality of power, and finally power. Politics can also be said as wisdom, power, government power, conflict management which becomes the national consensus and the power of the masses of the people. ${ }^{4}$

Political participation is not new in the world of political science, this is to see the extent to which the level of public participation in politics is either conventional or unconventional. Political participation according to Herbert McClosky is the voluntary activities of citizens through which they take part in the process of selecting rulers and directly or indirectly in the process of forming public policies. ${ }^{5}$ While Huntington and Nelson said political participation is the activity of citizens who act as individuals with the intention of influencing government

\footnotetext{
${ }^{1}$ Abdul Manan, Perbandingan Politik Hukum Islam dan Barat, (Jakarta: Prenada Media, 2018), p. 1. ${ }^{2}$ https://kbbi.web.id/politik

${ }^{3}$ Hasan Shadili, Ensiklopedi Indonesia, Ichtiar Baru van Hoeve, Jakarta, 1983, p. 2739

${ }^{4}$ Abdul Manan. Op.Cit., p. 2.

${ }^{5}$ Herbert MCCLOSKY. 1981. Political Particpation, dalam Mariam Budiarjo, Partisipasi dan Partai Politik. Jakarta. PT Gramedia p. 1
} 
decision-making. Participation can be individual or collective, continuous or sporadic, peaceful or violent, legal or illegal, effective or ineffective. ${ }^{6}$ Miriam Budiarjo, political participation is the activity of a person in a political party. Political participation includes all voluntary activities through which a person participates in the process of electing political leaders and participates directly or indirectly in the formation of public policy. ${ }^{7}$

The above definition can be concluded that the concept of political participation refers to the activities of citizens (as private sector) in two main things, namely in the process of selecting the elected ruler. This second activity is in the form of influencing the public decision-making process (policy). ${ }^{8}$ Activities that are considered a form of political participation usually include: voting in general elections, becoming a member of a political party, and so on.

Elections as a form of political participation are the most appropriate and ideal form of democracy for all modern political and social organizational systems today. Democracy as the basis life. The state generally provides an understanding that at the last level, it is the people who provide provisions in the main issues regarding their lives, including in assessing government policies, because these policies determine the lives of their people. Meanwhile, a democratic state is a state that is organized based on the will and power of the people, or if viewed from an organizational point of view, it means as a state organization carried out by the people themselves or with the consent of the people because sovereignty is in the hands of the people. ${ }^{9}$ Countries that proclaim themselves as democracies usually hold general elections to elect public officials in the executive and legislative circles, which are also held at the center and in the regions. Democracy and democratic elections are mutually "qonditio sine qua non", the one can not exist without the others. ${ }^{10}$

The general election system in political science can be divided into two, namely: the district representative system (single member constituency) and the proportional representation system (multi-member constituency). ${ }^{11}$ The purpose of holding elections is to elect representatives of the people and regional representatives to form a democratic, strong government and gain popular support in order to realize national goals. Principles of Elections are carried out effectively and efficiently based on the principles of direct, general, free, confidential, honest and fair. Indonesia as a democratic country conducts general elections directly by the people against their representatives in both the executive and legislative

\footnotetext{
${ }^{6}$ Samuel P. Huntington and Joan M. Nelson. 1977. No Easy Choice: Political Participation in Developing Countries . Cambridge Mass. Hardvard University Press. p. 3

${ }^{7}$ Herbert McClosky. Op. cit. p. 52.

${ }^{8}$ Amatullah Shafiyyah. 2003. Kiprah Politik Muslimah: Konsep Dan Implementasinya. Jakarta. Gema Insani, p. 42.

${ }^{9}$ Moh. Mahfud MD. 1993. Demokrasi dan Konstitusi di Indonesia, Studi tentang Interaksi Politik dan Kehidupan Ketatanegaraan. Yogyakarta. Liberty, p. 2.

${ }^{10}$ Bandingkan Abdul Mukthie Fadjar, "Pemilu yang Demokratis dan Berkualitas: Penyelesaian Hukum Pelanggaran Pemilu dan PHPU”, Jurnal Konstitusi Volume 6 Nomor 1, April 2009, p. 4.

${ }^{11}$ Jean Blondel. 1954. An Introduction to Comparative Government. London, Methuen and Co. Ltd: p. 177-206.
} 
institutions. The implementation of this general election in Indonesia is the embodiment of Article 1 paragraph (2) of the Constitution of the Republic of Indonesia 1945.12 Some of the regulations regarding general elections in Indonesia can be seen below:

- Law of the Republic of Indonesia Number 1 of 2015 concerning Stipulation of Perppu Number 1 of 2014 concerning the Election of Governors, Regents, and Mayors into Law, as has been amended several times, most recently by Law of the Republic of Indonesia Number 10 of 2016 concerning the Second Amendment to Act No. 1 of 2015 concerning Stipulation of Perppu Number 1 of 2014 concerning the Election of Governors, Regents, and Mayors into Law, as the legal basis for the implementation of post-conflict local elections some time ago;

- Act No. 7 of 2017 concerning General Elections, as the legal basis for the implementation of the presidential and legislative elections, which is a reflection of RI Act No. 42 of 2008 concerning the General Election of the President and Vice President, Law of the Republic of Indonesia Number 8 of 2012 concerning General Elections for Members of DPRD, DPD, and DPRD, as well as Law of the Republic of Indonesia Number 15 of 2011 concerning the Implementation of General Elections.

In fact, in Indonesia the motto of democracy "of the people by the people and for the people" must be paid a heavy price for a political contestation through clean and true elections to produce the expected leaders. The high cost in terms of holding general elections is also followed by the high costs that may be incurred by candidates for representatives of the people as contestants. ${ }^{13}$

Starting from the nomination process through a political vehicle to get recommendations and amenities parties, to the attempt to seize voters through various persuasive approaches, creating great potential for the practice of money politics. Starting from the giving of money with the theme of humanitarian aid, to the onslaught of "dawn attacks" are some of the hidden variants of modifying the practice of money politics. It is an attempt to influence other people (society) by using material rewards or it can also be interpreted as buying and selling votes in the political process and power as well as the act of distributing money, whether privately owned or by parties to influence voter votes (Money Politics) can be interpreted as an effort to influence the behavior of others by using certain rewards. Some interpret money politics as an act of buying and selling votes in the political process and power. ${ }^{14}$

The practice of money politics can be said to be the forerunner of political corruption. Because money politics, which he calls transactional politics, has the potential to be destructive continuity government order. Because, a public officials

\footnotetext{
${ }^{12}$ Article 1 paragraph (2) of the 1945 Constitution of the Republic of Indonesia: Sovereignty rests with the people and is implemented according to the law.

${ }^{13}$ Handoko Alfiantoro, Posisi Hukum Tindak Pidana Korupsi Politik Sebagai Bagian dari Refleksi Praktik Politik Uang, Seminar Nasional Hukum Universitas Negeri Semarang Volume 4 Number 3 of 2018, p. 936.

14Thahjo Kumolo. 2015. Politik Hukum PILKADA Serentak. Bandung: PT Mizan Publika. p. 155.
} 
in the executive and legislative circles both at the center and in the regions who carry out money politics to get themselves elected, it is possible to find a way to get back the capital that has been spent during the practice of money politics in the previous election process.

Type variant concept New corruption crimes which are not specifically regulated in the legislation but are now becoming familiar are mentioned. Corruption and politics are always interesting to be discussed, but until now, although money politics has the potential to cause corruption. The Law of the Republic of Indonesia Number 7 of 2017 concerning General Elections has not included money politics in a separate article. Even though we know that the crime of money politics as a criminal act of corruption deserves to be made a separate offense in a material criminal law regulation. This crime of corruption is not only carried out by the government (executives), but is also carried out by elements in the legislative, judicial and private institutions. ${ }^{15}$

Based on the description above, this study aims to find out and analyze the reformulation of money politics in the election law as a criminal act of corruption.

\section{Research Methods}

The research method used in this paper uses a normative juridical approach. The research data includes secondary data which includes primary legal materials in the form of related legislation, legal materials and tertiary legal materials. Data was collected by using the literature study method. The method of analysis used descriptive analytical.

\section{Results and Discussion}

Money politics is not new in elections in Indonesia. In the first general election in 1955, money played an important role in the process of winning political parties. The party pays people who have influence, such as sub-district heads, village head, foremen, heroes, to use their influence to win the party. This is usually done at the end of the campaign. The main source of party funds comes from political corruption. They use ministerial positions to channel money into party coffers or use patronage to gain influence or indirect funding. Sources of party funds can also come from business. PNI has additional sources of income from Indonesian and Chinese business groups, PKI from donations from Chinese business groups, and Masyumi from land owners and batik entrepreneurs. ${ }^{16}$

Money politics in Indonesia has indeed become a tradition and complementary seasoning in general elections in Indonesia. Since ancient times, the practice of money politics in Indonesia has existed for a long time, namely since the New Order era, which had a greater opportunity to practice money politics, because during the

\footnotetext{
${ }^{15}$ Novita Ilmaris and Arpangi. "Reform of Bureau of Public Services in Framework of Prevention \& Eradication of Corruption in Indonesia" in Law Development Journal Volume 2 Issue 4, December 2020, p. 637 URLs:http://jurnal.unissula.ac.id/index.php/ldj/article/view/15351

${ }^{16}$ Ade Irawan, Abdullah Dahlan, Donal Fariz, dan Almas Ghalia Putri. 2014. Pandauan Pemantauan Korupsi Pemilu, Jakarta. Indonesia Corruption Watch. p. 47.
} 
new order, the president was appointed by the MPRS/DPRD which consisted of several members. In addition, the regional elections during the new order were not directly elected as they are today, but regional heads were appointed by the president, whose election mechanism in the DPRD was also controlled by the president so that in practice there was a great opportunity for the president to carry out money politics to the DPRD so that the leaders in each region in accordance with the central government. ${ }^{17}$

Money Politics is a problem that endangers the morality of the nation, although economically in the short term it can provide a little help to the small people who participate. However, whether short-term economic goals must sacrifice long-term goals in the form of democratization efforts and the formation of national morality. The demoralization caused by Money Politic will be very dangerous both in terms of deontological (intentions) and theological (consequences). Because of its destructive nature, that is, it intends to influence a person's political choice with a certain reward, or to influence the vision and mission of a party so that the political choices of its policies can no longer be accounted for in the interests of the people.

Money politics in general elections can also be called bribery. The crime of bribery corruption stems from the crime of bribery originating from the Criminal Code, in the Criminal Code itself is divided into two groups of bribes, namely the crime of not giving bribes and the crime of accepting bribes. The first group, commonly referred to as active bribery, the legal subject of which is giving bribes is loaded and becomes part of crimes against the general authorities, namely Article 209 and Article 210 of the Criminal Code. The second group, which is commonly referred to as passive bribery, the legal subjects are civil servants who accept bribes. Loaded and become part of the crime of office, namely Article 418, Article 419, Article 420 of the Criminal Code. ${ }^{18}$

A bribe or bribe is a gift in the form of a gift given to another person with the expectation of a certain reward of greater value. ${ }^{19}$ In Act No. 11 of 1980 concerning the Crime of Bribery Article 2 and Article 3 states that what is meant by a bribe or bribe is: "... giving or promising something to someone with the intention of persuading that person to do something or not to do something in their duties, which is contrary to the authority or obligations that concern the public interest, ... "... accept something or a promise, while he knows or can reasonably suspect that the giving of something or a promise is intended so that he does something or does not do something in his duties, which is contrary to his authority or obligation, which concerns the public interest, ...". Based on the above definition, it can be concluded that an act can be classified as a bribe if it fulfills several elements,

\footnotetext{
${ }^{17}$ Jonasmer Simatupang, Muhammad Subekhan,Pengaruh Budaya Politik Uang dalam Pemilu Terhadap Keberlanjutan Demokrasi Indonesia, Seminar Nasional Hukum Universitas Negeri Semarang Volume 4 Number 3 of 2018, p. 1304-1305.

${ }^{18}$ Anis Widyawati, Potensi Tindak Pidana Korupsi dalam Pesta Demokrasi Pemilihan Kepala Desa, Seminar Nasional Hukum Universitas Negeri Semarang Volume 4 Number 2 of 2018, p. 390.

${ }^{19}$ Wisnu Pratama Iryanto, Menelisik Tindak Pidana Politik Uang Pada Pilkada Serentak 2018 (Studi Kasus di Kabupaten Kuningan dan Kabupaten Ternate),Semarang State University Law National Seminar Volume 4 Number 2 of 2018, p. 259.
} 
namely: ${ }^{20}$ a. The existence of a gift or promise that aims to attract the sympathy of others. b. The giving or promise with the aim of canceling what is right, realizing falsehood, seeking unjustified partiality, getting something that is not rightfully his or winning the case.

The formulation of criminal acts of corruption according to Article 1 of Act No. 30 of 2002 concerning the Corruption Eradication Commission states that the Criminal Act of Corruption is a criminal act as referred to in Act No. 31 of 1999 concerning Eradication of Corruption Crimes as amended by Act No. 20 of 2001 concerning Amendment to Act No. 31 of 1999 concerning the Eradication of Corruption Crimes.

Literally corruption is something that is rotten, evil, and destructive. If you discuss the problem of corruption, you will find such a reality because corruption involves moral aspects, rotten nature and conditions, positions in government agencies or apparatus, abuse of power in office due to gifts, economic and political actors, and placement of families or groups into official service under his authority. Thus literally it can be concluded that the term corruption actually has a very broad meaning, namely: ${ }^{21}$

- Corruption, misappropriation or embezzlement (state or company money and so on) for personal or other people's interests;

- Corruption, Rotten; Broken; likes to use goods or money entrusted to him; can be bribed (through his power for personal gain).

The provision of bribes in electoral practice is regulated in Article 149 of the Criminal Code, namely anyone who at the time of an election held based on general rules by giving or promising something, bribing someone so as not to exercise their right to vote or exercising that right in a certain way, is threatened with a maximum imprisonment of Nine months or a maximum fine of IDR 4,500.

Sanctions for perpetrators of money politics or money politics have also been specifically regulated in Act No. 20 of 2001 concerning Corruption Crimes, namely Article 5 which contains:

1) Sentenced to a minimum imprisonment of 1 (one) year and a maximum of 5 (five) years and or a minimum fine of IDR 50,000,000.00 (fifty million rupiah) and a maximum of IDR 250,000,000.00 (two hundred and five tens of millions of rupiah) every person who:

a. give or promise something to a civil servant or state administrator with the intention that the civil servant or state administrator do or not do something in his position, which is contrary to his obligations; or

b. giving something to a civil servant or state administrator because of or in connection with something that is contrary to his obligations, done or not done in his position.

2) For civil servants or state administrators who receive gifts or promises as referred to in paragraph (1) letter a or letter $b$, shall be subject to the same punishment as in paragraph (1).

\footnotetext{
${ }^{20}$ Hepi Riza Zen, Politik Uang dalam Pandangan Hukum Positif dan Syariah, Jurnal Al Adalah Volume 12, Number 3, p. 533.

${ }^{21}$ Evi Hartanti. 2005. Tindak Pidana Korupsi, Jakarta. Sinar Grafika. 2005. p. 21.
} 
Generally, money politics will lead to corruption, corruption that is rife is a form of budget deviation that occurs because of the cooperation between the executive and the legislature. The presence of the legislature with a control or supervisory function does not function optimally. This point is related to the second point above, namely the motivation for corruption is to restore the losses that occurred during the campaign, namely that the candidate has carried out money politics in order to fool the people in order to gain votes. ${ }^{22}$

In order to strengthen the legal position of the general election, it is time for lawmakers to reformulate money politics in the election law as a corruption crime. This can be done by including a clause on the criminal act of political corruption as a special offense in the General Election Law so that it can become a strong legal basis for law enforcement officials to take preventive or repressive steps to realize clean and political elections that are clean and fair corruption free.

Why there are still many money politics practices in the holding of the 2019 simultaneous elections, one of which is due to the weakness of regulations regarding money politic in the election becomes a setback when compared to the pilkada. He compared one of the points, on the pilkada, the giver and the receiver. ${ }^{23}$

Law enforcement and the imposition of strict and indiscriminate sanctions are something that absolute must be enforced if we want to eliminate the practice of money politics. This is related to public trust in election organizers, especially the Supervisory Committee and other Law Enforcers. So it is appropriate that pit is necessary to have a clear and clear understanding or formulation of money politics as part of the criminal act of corruption in the laws and regulations, especially the laws and regulations concerning general elections. Thus, at a minimum, ambiguous interpretations of the practice of money politics can be avoided.

In the preamble to the Corruption Law, it has been stated that corruption is very detrimental to state finances or the state economy and hinders national development, as well as hinders the growth and continuity of national development which demands high efficiency so that it must be eradicated in order to create a just and prosperous society based on Pancasila and the 1945 Constitution. Therefore, the law on the eradication of criminal acts of corruption continues to be updated so that it can be applied effectively in the prevention and eradication of corruption. ${ }^{24}$

In the context of preventing and eradicating corruption in the future, there are several things that can be used as material for reflection and thought, namely harmonization of laws and regulations in the context of preventing and eradicating corruption; revitalization and actualization of the roles and functions of law enforcement officials who handle corruption cases; reformulation of the functions

\footnotetext{
22Jonasmer Simatupang, Muhammad Subekhan. Op cit, p. 1310.

${ }^{23}$ Karto and Akhmad Khisni. "Islamic Views on Money Political Practices in the Constitutional Election of 2019". Law Development Journal Volume 2 No 2, June 2020 p. 157-158, url:http://jurnal.unissula.ac.id/index.php/ldj/article/view/11443

${ }^{24}$ Rully Trie Prasetyo, Age Ma'ruf, Anis Mashdurohatun, Tindak Pidana Korporasi Dalam Perspektif Kebijakan Formulasi Hukum Pidana. Jurnal Hukum Hukum Khaira Ummah Vol. 12. No. 4 December, 2017
} 
of the legislature. Eradication of criminal acts of corruption must start from the small things and start today so that every region is free from corruption. ${ }^{25}$

\section{Closing}

Reformulation of criminal acts of money politics in the election law as a criminal act of corruption can be carried out by including a clause on criminal acts of political corruption as a special offense in the General Election Law so that it can become a strong legal basis for law enforcement officials to take preventive measures or repressive to realize clean elections and corruption-free politics.

\section{References}

\section{Journals}

[1] Abdul Mukthie Fadjar, Pemilu yang Demokratis dan Berkualitas: Penyelesaian Hukum Pelanggaran Pemilu dan PHPU, Jurnal Konstitusi Volume 6 Nomor 1, April 2009.

[2] Haris Fadillah Harahap and Widayati. "The Law Enforcement against the Personnel of Corruption Crime" in Law Development Journal Volume 2 Issue 4, December 2020. p. $528 . \quad$ url: http://jurnal.unissula.ac.id/index.php/ldj/article/view/13640

[3] Hepi Riza Zen, Politik Uang dalam Pandangan Hukum Positif dan Syariah, Jurnal Al Adalah Volume 12, Nomor 3.

[4] https://kbbi.web.id/politik

[5] Karto and Akhmad Khisn. "Islamic Views on Money Politic Practices in the Constitutional Election of 2019". Law Development Journal Volume 2 No 2, June $2020 \quad$ p. 157-158, url: http://jurnal.unissula.ac.id/index.php/ldj/article/view/11443

[6] Novita Ilmaris and Arpangi. "Reform of Bureau of Public Services in Framework of Prevention \& Eradication of Corruption in Indonesia" dalam Law Development Journal Volume 2 Issue 4, December 2020, url: http://jurnal.unissula.ac.id/index.php/ldj/article/view/15351

[7] Rully Trie Prasetyo, Umur Ma'ruf, Anis Mashdurohatun, Tindak Pidana Korporasi Dalam Perspektif Kebijakan Formulasi Hukum Pidana. Jurnal Hukum Hukum Khaira Ummah Vol. 12. No. 4 December 2017

\section{Books}

[1] Abdul Manan. 2018. Perbandingan Politik Hukum Islam dan Barat. Jakarta. Prenada Media.

[2] Ade Irawan, Abdullah Dahlan, Donal Fariz, dan Almas Ghalia Putri. 2014. Pandauan Pemantauan Korupsi Pemilu, Jakarta. Indonesia Corruption Watch.

[3] Amatullah Shafiyyah. 2003. Kiprah Politik Muslimah: Konsep Dan Implementasinya. Jakarta. Gema Insani.

\footnotetext{
${ }^{25}$ Haris Fadillah Harahap and Widayati. "The Law Enforcement against the Personnel of Corruption Crime" in Law Development Journal Volume 2 Issue 4, December 2020. page 528. url:http://jurnal.unissula.ac.id/index.php/ldj/article/view/13640
} 
[4] Anis Widyawati, Potensi Tindak Pidana Korupsi dalam Pesta Demokrasi Pemilihan Kepala Desa, Seminar Nasional Hukum Universitas Negeri Semarang Volume 4 Nomor 22018.

[5] Evi Hartanti. 2005. Tindak Pidana Korupsi, Jakarta. Sinar Grafika. 2005.

[6] Handoko Alfiantoro, Posisi Hukum Tindak Pidana Korupsi Politik Sebagai Bagian dari Refleksi Praktik Politik Uang, Seminar Nasional Hukum Universitas Negeri Semarang Volume 4 Nomor 32018.

[7] Hasan Shadili. 1983. Ensiklopedi Indonesia, Ichtiar Baru van Hoeve. Jakarta.

[8] Herbert MCCLOSKY. 1981. Political Particpation, dalam Mariam Budiarjo, Partisipasi dan Partai Politik. Jakarta. PT Gramedia.

[9] Jean Blondel. 1954. An Introduction to Comparative Government. London, Methuen and Co. Ltd:

[10] Jonasmer Simatupang, Muhammad Subekhan,Pengaruh Budaya Politik Uang dalam Pemilu Terhadap Keberlanjutan Demokrasi Indonesia, Seminar Nasional Hukum Universitas Negeri Semarang Volume 4 Nomor 32018.

[11] Moh. Mahfud MD. 1993. Demokrasi dan Konstitusi di Indonesia, Studi tentang Interaksi Politik dan Kehidupan Ketatanegaraan. Yogyakarta. Liberty.

[12] Samuel P. Hutington dan Joan M. Nelson. 1977. No Easy Choice: Political Participation in Developing Countries. Cambridge Mass. Hardvard University Press.

[13] Thahjo Kumolo. 2015. Politik Hukum PILKADA Serentak. Bandung: PT Mizan Publika.

[14] Wisnu Pratama Iryanto, Menelisik Tindak Pidana Politik Uang Pada Pilkada Serentak 2018 (Studi Kasus di Kabupaten Kuningan dan Kabupaten Ternate), Seminar Nasional Hukum Universitas Negeri Semarang Volume 4 Nomor 2 2018. 